Article

\title{
Challenging the Nation-State from within: The Emergence of Transmunicipal Solidarity in the Course of the EU Refugee Controversy
}

\author{
Christiane Heimann ${ }^{1}$, Sandra Müller ${ }^{1}$, Hannes Schammann ${ }^{1}$ and Janina Stürner ${ }^{2, *}$ \\ ${ }^{1}$ Migration Policy Research Group, University of Hildesheim, 31141 Hildesheim, Germany; \\ E-Mail: heimann@uni-hildesheim.de (C.H.), sandra.mueller@uni-hildesheim.de (S.M.), \\ hannes.schammann@uni-hildesheim.de (H.S.) \\ ${ }^{2}$ Centre for Area Studies, Friedrich-Alexander-University Erlangen-Nürnberg, 91054 Erlangen, Germany; \\ E-mail: janina.stuerner@fau.de \\ * Corresponding author
}

Submitted: 28 January 2019 | Accepted: 5 April 2019 | Published: 27 June 2019

\begin{abstract}
In the context of the so-called refugee crisis, political disputes about solidarity become a central issue with member states applying competing concepts. At the same time, European cities use transnational networks to implement a new form of solidarity among municipalities via city diplomacy (Acuto, Morissette, \& Tsouros, 2017). Analyzing the deadlock between member states and the emerging activities of cities, we scrutinize the limits of existing approaches to political solidarity (e.g., Agustín \& Jørgensen, 2019; Knodt, Tews, \& Piefer, 2014; Sangiovanni, 2013) to explain this phenomenon. Based on expert interviews and document analysis from a study on transnational municipal networks, we identify an emerging concept of solidarity that challenges the nation states as core providers of solidarity from within: transmunicipal solidarity focuses on joint action of local governments to scale out and scale up.
\end{abstract}

\section{Keywords}

city networks; concepts of solidarity; European Union; integration policy; migration policy; refugee controversy

\section{Issue}

This article is part of the issue "The European Refugee Controversy: Civil Solidarity, Cultural Imaginaries and Political Change", edited by Gert Verschraegen (University of Antwerp, Belgium) and Robin Vandevoordt (University of Oxford, UK/University of Antwerp, Belgium).

(C) 2019 by the authors; licensee Cogitatio (Lisbon, Portugal). This article is licensed under a Creative Commons Attribution 4.0 International License (CC BY).

\section{Introduction}

Solidarity-or rather the lack of solidarity-had become a contested topic already during the Euro crisis from 2007 onwards. Although solidarity has been formalized in Article 80 TFEU, its meaning is formulated only vaguely (Karageorgiou, 2016). Consequently, back then, discussions arose about financial aid and burden sharing between member states (Billmann \& Held, 2013; Kneuer \& Masala, 2014; Wallaschek, 2018). Although solutions and solidarity mechanisms were created, there never seemed to be a broad consensus or even a model for dealing with potential crises in the future. When the refugee controversy hit Europe several years later, the quest for solidarity continued and even intensified. In this context, the concept of solidarity refers to two dimensions: firstly, an internal dimension that calls for the "burden sharing" between member states, and secondly, an external dimension when it comes to mitigating the consequences of increasing numbers of displaced persons worldwide. It might not come as a surprise that the EU has failed to develop any solid solidarity mechanism that could be accepted by all member states. This is not only true for the external dimension, but even for the internal one, which has been at the center of attention for the European Commission and the member states (Thielemann, 2017).

Knodt, Tews and Piefer (2014, p. 121) underline that different perspectives on solidarity and different political representations of solidarity are likely to clash in con- 
tested sectors such as refugee reception. Consequently, the debate on solidarity in Europe has never before been as intense, chatoyant, diverse and fragmented as it has become during the so-called refugee crisis. Following Mayer (2018) and Agustín and Jørgensen (2019), this has also become relevant for the subnational level, especially in response to more restrictive measures on both the EU and the national level. Local administrations as well as civil society actors increasingly engage in the debates on the entry and resettlement of asylum-seekers and refugees. While the efforts of EU member states to reach an agreement on how to proceed with the Common European Asylum System seem to go around in circles, it is the municipalities and their networks that offer solutions. When nation-states refused rescue ships safe harbor in the Mediterranean, among others the mayors of Barcelona (Ajuntament de Barcelona, 2018), Naples (Balmer, 2019), Bonn, Cologne and Düsseldorf (Welt, 2018) offered to host asylum seekers. They put their nation states under pressure, which resulted in their taking in a limited number of refugees rescued in the Mediterranean (Braun, 2019; FAZ, 2018; Welt, 2018). In order to influence migration and integration policies, cities also make use of their network structures at EU level such as Eurocities or create new ones, such as Solidarity Cities.

These developments take place within a broader debate on "city diplomacy" or, more generally, on municipal strategies and coalitions to engage beyond the national territory (e.g., Acuto \& Rayner, 2016; Aldecoa \& Keating, 1999; Alger, 2011; Barber, 2014; Chan, 2016; Lecours, 2002; Marchetti, 2016; van der Pluijm \& Melissen, 2007). Over the past 15 years, new opportunities for political participation have been opening up for municipalities and transnational municipal networks (TMN), especially within the EU multi-level system (Acuto, Morissette, \& Tsouros, 2017, pp. 14-22; Zapata-Barrero, Caponio, \& Scholten, 2017). TMNs have a long tradition in working directly with the European Commission and other EU institutions. Achievements like the "Committee of the Regions" (established as early as in 1994) and especially the "Urban Agenda for the EU" of 2016 helped to even institutionalize municipal participation on EU level. TMNs engage in the fields of environment, climate, poverty and peace (Acuto \& Rayner, 2016, p. 1153).

In this article, we will trace the question of whether the activities of TMNs in the field of refugee reception could be conceptualized as a new form of cross-border solidarity provided by government levels other than the national one. To this end, we firstly trawl through the growing theoretical debate on political solidarity in order to identify concepts to build on (e.g., Agustín \& Jørgensen, 2019; Knodt et al., 2014; Sangiovanni, 2013, 2015). Secondly, we analyze the activities of TMNs in the European refugee controversy, exemplified by Eurocities and its sub-networks Integrating Cities and Solidarity Cities. In doing so, we will introduce an emerging concept of solidarity that thrives while others fade: transmunicipal solidarity. This concept originates from practices of "institutionalized solidarity" (Agustín \& Jørgensen, 2019, pp. 97-117) on the local level, focuses on local governments but is nurtured by the interplay of state and nonstate actors.

\section{Analytical Framework: Rethinking Political Solidarity in EU Refugee Reception}

In philosophy and social sciences, a rather comprehensive body of literature is available on solidarity, dating back to Durkheim (1933) and Weber (1925). In this contribution, however, we will focus on more recent approaches to political solidarity (Scholz, 2008). Following Sangiovanni (2015), we understand solidarity as joint action between people/groups/political entities who share the same goal "to overcome some significant adversity" (Sangiovanni, 2015, p. 343). They advance that goal without "bypassing each other's will" (Sangiovanni, 2015, p. 343). Building on that basic definition, we can identify two important aspects for conceptualizing political solidarity: Firstly, there is no such thing as unilateral solidarity. Consequently, actors do not express solidarity with each other if some of them do not share the same goal, do not see the same urgency of an adversity or seek to dodge political or financial costs of a joint effort. Secondly, solidarity requires action with another rather than on behalf of another (p. 350). From that point of view, national governments usually do not act in solidarity with individuals, e.g., refugees, but rather act on behalf of them, i.e. perform an asymmetrical act of charity. In this contribution, we focus on joint actions of comparable communities or political entities in the EU indicating solidarity with another in the refugee controversy. The institutionalization of solidarity between individuals within a community, however, can determine how communities and their local governments act (Agustín \& Jørgensen, 2019).

Political solidarity is often viewed through a national or European lens. Sangiovanni (2013), identifies three main manifestations for political solidarity in the European Union: "national solidarity", "member state solidarity" and "transnational solidarity". National solidarity refers to the relationship of citizens and residents within member states. It does, therefore, not apply directly to the question addressed in this article. Member state solidarity, on the other hand, is discussed most frequently in European asylum politics. It is often referred to as "intergovernmental solidarity" (Knodt et al., 2014) or "interstate solidarity" (Karageorgiou, 2016). Concerning refugee reception, it leads to the question of how "burden sharing" amongst EU member states can be organized (cf. Bauböck, 2017). Following Knodt et al. (2014), the intergovernmental quest for solidarity can be replaced or at least accompanied by "supranational solidarity". In this concept, the EU's "sui generis" character establishes a second political community that demands joint action on the basis of the treaties and also involves EU organizations. However, the nation states remain the 
principal actors of solidarity. It might not come as a surprise that taking member state solidarity (or any of the related concepts) as a framework for analyzing the deadlock in European asylum politics unequivocally leads to the conclusion that there is not much political solidarity left regarding refugee reception in the European Union. The main reason is that member states do not share the same goal, which creates diverging perceptions and claims for solidarity as we will elaborate on further down the line.

With member state solidarity ailing, the basic research question of this article steps in: Is there any form of cross-border solidarity in Europe concerning refugee reception and "burden-sharing" which is emerging from another government level than the national one? Sangiovanni's (2013) third manifestation of political solidarity-transnational solidarity-might serve as a starting point. It places emphasis on social movements and/or individual commitment originating on the local level and developing strong bonds with individuals/groups across borders. Transnational solidarity, therefore, introduces actors below and beyond the nation state as providers of solidarity. However, Sangiovanni's definition of transnational solidarity does not encompass any form of government or administration. This is also true for the vast majority of concepts on solidarity that take the local level into account but limit themselves to civil society (e.g., Finke \& Knodt, 2005; Knodt et al., 2014). Especially when it comes to refugee reception, though, local authorities play a crucial role in providing shelter, food or health care. Consequently, there cannot be any talk of "burden sharing" between local communities without involving local administrations.

While local authorities had for a long time been considered to be merely implementing actors-and not just in the field of refugee reception and migrationthe increasing awareness of the fact that global challenges such as migration and displacement have to be addressed at the local level, has changed that view (e.g., Caponio \& Borkert, 2010; Hinger, Schäfer, \& Pott, 2016; Kos, Maussen, \& Doomernik, 2015; Zapata-Barrero et al., 2017). Following Rosenberger and Müller (2019), municipalities can in times of conflicts establish structures to oppose and contradict national refugee policies, both protesting against the reception of asylum-seekers and balancing out national shortcomings. As Agustín and Jørgensen (2019) illustrate for the city of Barcelona, local practices and policies might result in a coherent pattern of solidarity mechanisms, e.g., a local strategy that involves concepts on refugee reception as well as organizational arrangements and a supportive local political culture. Thus, the municipality can evolve into a place of "institutional solidarity" (Agustín \& Jørgensen, 2019). Reaching out to likeminded municipalities, cities like Barcelona create a network that transcends regional and national borders, thus scaling up their ideas to have an impact on other political levels (Agustín \& Jørgensen, 2019). This is in line with Mayer (2018) who argues that municipalities contradicted this approach with welcoming stances and "established a network to advocate for migrant-friendly policies across the EU" (p. 232) as a response to more restrictive asylum policies on the national level.

In Agustín and Jørgensen's (2019) study, Barcelona's scaling up-activities are conceptualized within the "institutional solidarity" developed on the local level. However, following Sangiovanni (2015), it might be useful to distinguish between the solidarity among local people and the solidarity among likeminded cities. Roth and Russell (2018) introduce the concept of "translocal solidarity" that, prima facie, seems to provide us with a solution. From their perspective, local movements develop solidarity amongst each other in order to strengthen their own capacities (scaling out). However, in this concept, municipalities and/or local movements do not necessarily aim at scaling up, i.e., influencing the national or even higher levels. Translocal solidarity also conceptualizes local authorities rather as a potential element of the local movements but not as the main provider of crossborder solidarity.

Based on the analysis of our data on TMN presented below, we found empirical evidence for another manifestation of political solidarity which is not covered by the existing concepts. It captures (1) joint action amongst municipalities with (2) a focus on local governments and/or authorities whose common goals are (3) to scale out in terms of capacity building (4) and to strategically scale up their policy agenda via city diplomacy. We call this concept "transmunicipal solidarity". From the concepts of transnational and translocal solidarity, it inherits the focus on sub-national providers of solidarity. However, it is not primarily driven by civil society actors but instead roots in the debate on burden sharing-and thus member state and intergovernmental solidarity. This accounts for a strong emphasis on local authorities. Focusing on the case of Eurocities and its sub-networks Integrating Cities and Solidarity Cities, we will illustrate the concept in the following sections.

\section{Methodological Approach}

For our analysis of political solidarity expressed by TMNs, we triangulated data from document analysis and expert interviews (Denzin, 2014; Denzin \& Lincoln, 2011). The documents derive from the networks' websites, reports, policy statements and recommendations. They offer insights into both activities of scaling out and scaling up. In addition, we conducted 49 interviews with experts on EU migration policies and city networks in two waves: 21 interviews in autumn 2018 and 28 interviews in spring 2019. These experts included members and representatives of the TMNs analyzed in this contribution, such as Eurocities, Integrating Cities and Solidarity Cities. Furthermore, we interviewed experts from the Council of European Municipalities and Regions (CEMR), the Committee of the Regions (CoR), URBACT, various 
think tanks, administrative bodies on local, national and EU-level, Members of the EU Parliament, Members of the European Commission, especially from the LIBE Committee, researchers, and NGOs working on migration, asylum and integration. We identified and contacted the experts in a two-step approach. Firstly, we identified relevant networks, members and representatives via desk research. In a second step, a snowball system was initiated in which interviewed experts recommended other relevant experts. We developed interview guidelines and informed our interview partners about the research project and the basic objectives. All quotes are taken from the interview transcripts mentioned above. Direct quotes will be associated with (groups of) organizations but not with specific individuals. Therefore, no further references will be done given.

We assessed the data by methods of qualitative content analysis (Gläser \& Laudel, 2010; Mayring, 2000). The data supplies comprehensive information on the policy activities of TMNs and their reasons to pursue specific political objectives. In this article, we will mainly focus on our findings for "scaling out" and "scaling up" of TMNs, exemplified by Eurocities and their cooperation partners. As a category, scaling out is indicated in the data, by way of example, whenever we find narratives or reports on activities of knowledge exchange or workshops on good practice. On the other hand, text segments are marked as "scaling up" if they entail, for instance, lobbying or the consultation of EU-bodies.

\section{Political Solidarity in Practice: From Member State Solidarity to Transmunicipal Solidarity}

Presenting our empirical data on TMNs we will, in a first step, briefly sketch how conflicts of interests and national circumstances among EU member states prevent national governments from finding an EU-wide solidarity approach-leaving the floor to new actors engaging in solidarity mechanisms. Secondly, we will illustrate how municipalities try to step in by living-up to the concept of transmunicipal solidarity.

\subsection{Turning the Back on Supranational Solidarity: Flexible Member State Solidarity}

As mentioned before, there is not much left of member state solidarity in the EU when it comes to refugee reception. Although all member states have implemented more restrictive refugee policies since 2015 (Bendel, 2018), there is also much divergence. To begin with, the refugee controversy is fueled by the fact that there is no agreement on the meaning of solidarity in the EU as several of our interview partners highlighted. A member of the European Parliamentary Research Service explained most precisely:

The problem is that solidarity is not yet described by a real definition in our treaties. It appears four times in European treaties - the word solidarity and we also have the word responsibility..., it is about financial responsibility but it is in itself Eurocentric. It is not about burden sharing with migrants.

Moreover, referring to Sangiovanni's basic definition of solidarity (Sangiovanni, 2015), member states do not share the same goal or even the same assessment of the adversities to overcome. Depending on their specific situation as recipients of asylum-seekers and their stance on the refugee controversy, EU member states can be grouped on a continuum in terms of their asylum policies and their degree of restrictiveness according to Bendel (2018). We examined the type of solidarity these classified groups do or do not show among and between each other.

The first group covers the Mediterranean states at the EU's external borders, such as Italy, Greece, Cyprus, Spain and Malta, which are mainly interested in border security, extraterritorial asylum procedures, and relocation of refugees. The second group supports the internal integration of refugees along with limited entry of refugees. In order to avoid intra-EU disputes on how to deal with refugees this group aims at a two-speed Europe in which countries that are willing to do so will receive refugees while others do not. France, Germany, Portugal, Luxembourg, Finland and Sweden belong to this group. These countries are interested in a coordinated EU foreign policy regarding immigration and asylum (Bendel (2018). As these two groups called for an EU-wide distribution key for member states to receive refugees, we claim that they support mechanisms of supranational solidarity. However, right-wing political forces put pressure on these countries to focus on active repatriation and integration rather than an EU-wide distribution key. The third group demands a more restrictive asylum and integration policy at EU level and includes countries such as Austria, Belgium, the Netherlands and Denmark. In these countries, governments and government coalitions include right-wing, conservative and/or populist parties. They focus on border security and reduce integration measures to avoid pull-effects that might trigger further refugee migration. The fourth group is the most restrictive one regarding asylum policies as it rejects immigration and integration of refugees; it includes countries such as the Czech Republic, Poland, Hungary and Slovakia. They refuse to receive refugees, foster border controls and deny integration measures in order to avoid pull-effects to attract additional immigration. These countries have low immigration rates and little experiences with refugee reception. Additionally, populist streams play a substantial role in these countries. United under the designation of Visegrad countries they build an alliance against refugee reception and relocation (Bendel (2018). We interpret this alliance as a mechanism of intergovernmental solidarity between member states for border security.

We conclude that each group of member states is united by a different cause, which enables them to show 
member state solidarity internally. However, looking at the EU as a whole, this creates diverging or even conflictive perceptions and claims for solidarity, leading to the widely adopted notion of a "solidarity crisis" in EU asylum politics. One of our interview partners working for an international organization remembered the emergence of the political buzzword "flexible solidarity" as an attempt to prevent the complete collapse of the Common European Asylum System:

Everybody has a different understanding of solidarity. The Bulgarian Presidency of the Council of the EU tried to open the term in order to achieve a buy-in of more member states. This was called "flexible solidarity", anything goes, however you may interpret the term. That's the beauty of constructive ambiguities.... On the one hand, you achieve a multilateral buy-in and therefore it is better to use a less determined term, a more open one. On the other hand, it leads to the point that solidarity becomes an empty, meaningless wording.

\subsection{The Eurocities Network: Using Cross-Border Solidarity among Municipal Authorities as a Political Tool}

The deadlock situation between member states and the eroding of the concept of member state solidarity opens a window of opportunity for actors on the sub-national level, especially those who are well organized across borders, above all TMN as a member of the Eurocities working group on migration and integration puts it in one of our interviews:

Transnational municipal initiatives are very interesting in a context, where Member States are abdicating not their rights but their obligations to participate as a Union.

\section{Another interview partner from Eurocities adds:}

Cities have a tendency to go over borders....There is of course a big discussion on the concept of borders, but for us borders are easy to overcome. This is not a question of being in favor or against an open border policy but for us cities it is easy to discuss without borders.

Especially larger cities do not only use the media by offering to receive refugees rescued in the Mediterranean, they also make use of their network structures at EU level, such as Eurocities, to foster political forms of solidarity. A member of Eurocities points out:

Solidarity as a principle is very useful. Politically we use it as cities in order to promote and implement policies saying that we show solidarity to each other and that we are there for each other.
The activities of Eurocities as well as its sub networks Integrating Cities and Solidarity Cities have had a particularly noticeable impact within the EU migration and integration policies based on forms of solidarity among municipalities, as we will examine in the following sections.

The Eurocities network was founded on the initiative of cities themselves and currently accommodates 140 big European cities (Eurocities, 2018). It is an influential lobby organization relying on voluntary coordination and a high degree of flexibility (Niederhafner, 2007, pp. 173-175) due to its specific organization. Membership is voluntary, the network constitutes nonhierarchical, horizontal and polycentric governance, and decisions are normally implemented by city members themselves (Kern \& Bulkeley, 2009). Generally, Eurocities is financially independent as it relies mainly on membership fees, although the network also makes use of other sources, such as EU funds or private (business) sponsors. The network is well connected to other institutions, including the European Commission, the European Parliament, the CEMR, the CoR and the United Nations. On this basis, Eurocities is able to develop common positions in a short amount of time and to voice the joint interests of the biggest European cities effectively within the decision-making processes in Brussels as highlighted by our interview partners. In contrast to other local movements described by Roth and Russell (2018), Eurocities explicitly involve different stakeholders on the local level, including municipal administration, civil society and authorities of the local government. Their representatives are typically mayors and/or administrative staff of local authorities.

The representatives of 79 cities form the Eurocities working group on migration and integration. It supports the visibility of cities and municipalities in the EU multilevel system for the integration of migrants and refugees. The working group has a long-standing tradition of knowledge exchange among member cities and supported the European Commission in developing a database on good practices of integration policies (Eurocities, 2018). Thus, the joint efforts of the city representatives in the working group are (1) to share experiences among its member cities and (2) to lobby the EU government to maximize the impact of cities' interests and expertise in EU migration and integration policies following a "bottom-up" approach. Contrary to the movements described in the concept of translocal solidarity (Roth \& Russell, 2018), Eurocities explicitly enforce the process of scaling out by sharing good practices but also the process of scaling up by influencing the policies on both the EU and the national level. An employee of a Transnational Municipal Network, who had worked as a policy consultant for many years before joining the network, claimed:

Local authorities engage at EU-level in these fields of migration asylum and integration policies, because they are the first in line. I think, for what I could see is that it has been the work of networks 
like Eurocities that actually make the EU-level institutions-Commission, Parliament, Council-to understand and to actually start changing their mindset and starting to involve cities really from designlevel, not only evaluation of policies and implementation, but really from the design point. They finally understood that the cities are actually the ones that are taking and adding on their shoulders all the burden that came from the recent crisis.

In this context, city diplomacy gains increasing importance. Firstly, municipalities deploy city diplomacy to create soft-law. Secondly, they develop strategies to hold national and European actors accountable by their own norms and values. Thirdly, cities increasingly demand a place at European negotiation tables (Stürner \& Bendel, in press). Thus, they play a crucial role in solidarity processes of scaling out and scaling up. In the following, different strategies aiming at fostering solidarity among Eurocities members will be introduced.

\subsubsection{Integrating Cities: A Platform for Scaling-Out}

In 2006, the Eurocities working group on migration and integration in cooperation with the European Commission launched the conference series Integrating Cities to enable interested Eurocities members to share good practices and develop recommendations. In this context, the Integrating Cities Charter was developed, which encourages local authorities to guarantee equal opportunities for and non-discrimination of all citizens (Eurocities, 2010). The Charter includes specific commitments launched by 17 European mayors at the Integrating Cities IV conference in London in February 2010. Until November 2018, it has since been signed by 39 cities and presents an interesting example of municipal soft governance that supports cities by offering them specific toolkits and evaluation reports published in 2013, 2015 and 2018 (Integrating Cities, 2018). Since 2007, the working group has directed projects on migration and integration, which have been funded by the INTI-Programm and the European Integration Fund. In the framework of the Integrating Cities process, cities developed benchmarks and peer-reviews for integration governance (INTI-CITIES), exchanged good practice for policy development to promote diversity (DIVE), created structured exchange workshops and toolkits to support cities in implementing the Integrating Cities Charter (MIXITIES) and addressed implementation gaps in migrant integration policies and practices through city-to-city mentoring schemes such as IMPLEMENTORING and CITIES GROW (Eurocities, 2018; Integrating cities, 2018).

This brief overview of the different projects within the network shows that Integrating Cities work together on capacity building to scale out by sharing good practices, setting local standards for immigrant integration and offering mutual mentoring. A member of this network confirmed:
Our work is mainly on sharing best practices, mutual learning, knowledge sharing. We try to foster that amongst our partners.

Hence, by scaling out Integrating Cities aims at creating soft law in the field of immigrant integration and fostering solidarity of participating cities. A member of the Eurocities working group on migration and integration underlines the value of this diverse local-to-local cooperation:

Cities help each other and I think that is also based a lot on solidarity because we are in this situation together....It is a curious mix of personal relationships but also political necessity, and political openness, because elected city representatives and administration have an open mind and understand if you invest time and money because it is necessary to help another fellow vice-mayor or another fellow director of services it will be beneficial for both sides. So, we pick each other's plates and we find good solutions.

\subsubsection{Solidarity Cities: Fostering Progressive Migration Policies through City Diplomacy}

Another sub-network of Eurocities which was explicitly formed by mayors to proactively take on the challenge of the so-called refugee crisis, is Solidarity Cities. The Mayor of Athens initiated and launched Solidarity Cities within the Eurocities network. Solidarity Cities strives to provide a framework for cities' actions and initiatives addressing the various adversities of the European "refugee crisis", describing itself as an "initiative on the management of the refugee crisis" that aims at "highlighting the political leadership of cities in addressing this challenge" (Solidarity Cities, 2019). As a representative of the City of Athens points out:

When cities speak about the Solidarity Cities initiative, not only in the Eurocities context but in the context of the work that they do in the European scene or globally, then they promote the idea of solidarity not only as a theoretical and philosophical concept but also as a political tool. This can help cities or countries to implement policies under difficult circumstances.

In Solidarity Cities, "the cities want to abide by the principles of responsibility and solidarity", as has been stated in an open letter from Eurocities for the International Refugee Day, 20 June 2016. The network is "open to all European cities wishing to work closely with each other and committed to solidarity in the field of refugee reception and integration" (Solidarity Cities, 2019). Solidarity Cities points out four main topics it is working on. Firstly, it fosters the exchange of information and knowledge on the reception situation in cities. Secondly, it lobbies for better involvement and direct funding for cities with regard to the reception and integration of 
refugees. In order to strengthen their position, they mobilized the support of Eurocities and members of the Urban Partnership. Thirdly, member cities support each other in this area by capacity building, as well as technical and financial assistance for active burden sharing. Fourthly, Solidarity Cities promotes the responsibility of European cities to receive relocated asylum seekers (Solidarity Cities, 2017).

As our interview partners stated, efforts to relocate refugees between member cities have been prevented by their nation states so far. For instance, Amsterdam was willing to take in refugees from Athens, but the Dutch government put an end to that already quite elaborate initiative as stated by our interview partners. Hence, the symbolic political value of Solidarity Cities still seems to be much higher than the measurable political output. Nevertheless, the network puts pressure on nation states, while raising public and political awareness to adversities of the "refugee crisis" and the need for crossborder solidarity in EU migration and integration policies. The structural integration of Solidarity Cities into the Eurocities networks is a big advantage as Eurocities as a platform substantially strengthens the political weight and visibility of Solidarity Cities. In this context, their achievement is to spread progressive ideas in the debate on refugee reception and integration. Their innovative political message provides a new framing of burden sharing and solidarity:

So, when you speak about solidarity, it's an emotional word, and it strikes to the emotional side of things, but you can also use it as a political tool. In between these two different concepts, it allows us to promote a discussion that is usually difficult and complicated.... think that this principle of solidarity and engagement and presence is very crucial for municipalities. Politicians should take these initiatives of local authorities very seriously, because the political change will come from the local authorities. (Member of Solidarity Cities)

In conclusion, we can say that Solidarity Cities aims at scaling out in the fields of refugee reception, immigration and asylum. Member cities share good practices, technical and financial resources and promote certain standards in the reception of refugees. Simultaneously, Solidarity Cities conducts active city diplomacy to scale up: Influencing other TMNs, such as Eurocities and the Partnership on Inclusion of Migrants and Refugees, they contribute to consultation processes of EU institutions and member states, engage in bilateral exchanges with these actors and demand a voice in areas that exceed municipal competencies such as irregular migration and relocation. Furthermore, the active lobbying of Solidarity Cities for better municipal access to the funding of reception and integration shows that this network is highly political, as has also been confirmed by our interview partners.

\subsubsection{Eurocities' Diplomatic Engagement with Other Players}

As stated above, Eurocities is a platform for different activities of scaling out and scaling up. However, the political activities of Eurocities reach beyond capacity building among their members and representing cities' voices at national and EU-level. There is a wider political engagement in city diplomacy. The network also constantly looks for cooperation partners and builds strategic alliances to improve the effectiveness of their capacity building and their lobbying strategies. On the local, regional and national level, Eurocities cooperates with a wide array of NGOs and companies in order to put the standards for integration policies they developed into practice. To find support for their political positions the Eurocities network builds alliances, especially with other networks that represent municipalities and/or regions of EU member states, such as the CEMR or the CoR as well as the national networks of cities and regions. City networks and like-minded initiatives work together to a certain extent to increase visibility and lend their demands greater weight. They do so especially for consultation purposes of the EU Commission.

Since 2016, cooperation between the Commission and local actors has been intensified by the "Urban Agenda for the EU", which was adopted in the Pact of Amsterdam. The goal is to improve cooperation between the Commission, member states and local stakeholders (such as city representatives, NGOs, etc.), so that local and regional players are more effectively involved in agenda setting and monitoring of EU provisions (European Commission, 2018). In this framework, the Partnership on Inclusion of Migrants and Refugees was established, which brings delegates of different networks and organizations together, such as representatives of cities, of the CEMR, the CoR, Eurocities or the European Development Bank and its Council. The Partnership adopted an Action Plan consisting of eight concrete actions developed by partnership members to improve regulation, funding and knowledge sharing. Examples include recommendations for better municipal access to EU integration funding, developed under the lead of Eurocities, the establishment of an Urban Academy on Integration and the elaboration of joint integration indicators (EU Partnership on Inclusion of Migrants and Refugees, 2017, 2018). Summarizing, we find that not only do TMNs demand a greater say in migration and integration policies, but also the Commission explicitly offers increasing structural opportunities for local and regional actors to participate in the political processes of agenda setting, monitoring and evaluation.

In this context, the efforts of TMN to scale up are accompanied by processes of coalition building with other important players focussing on the local and regional level and are politically active in the field of migration and integration policies. In this regard, TMNs take each other into account as important players for lobbying on 
the EU-level, which is also indicated by the overlapping and aggregation of city representatives' positions, as an employee of one of these networks explains:

And then you have some political authorities, where effectively this person is an international diplomat for the city or region. So there are a range of networks...and you can be a member of the CoR and at the same time you can be a member of Eurocities, at the same time you can be a member of something called Metropolis..., at the same time you have lots of members that go to the Council of Europe's local government wing. So, you have people that are essentially international diplomats for their region or city.

Thus, local authorities place themselves strategically in and between different networks in Brussels, which is proof of the relevance of city diplomacy on both local and EUlevel. These representatives pursue a diplomatic mission by aggregating positions in different European networks.

\section{Transmunicipal Solidarity: A Municipal Quest for Agency in the European Refugee Controversy}

In conclusion, our analysis of Eurocities and its subnetworks reveals a manifestation of political solidarity, which has not been covered by any other concept so far. It cannot be termed transnational solidarity (Sangiovanni, 2015) as it not only involves civil society, but also local administration and political leaders such as mayors. Furthermore, it does not fit in the concept of translocal solidarity (Roth \& Russell, 2018) as the emphasis is on local authorities and the solidarity among cities not only aims at scaling out but also at scaling up, making use of city diplomacy such as standard setting of good practices at horizontal level and lobbying at national and EU level. The TMNs analyzed in this article strategically use different instruments, including lobbying, public calls and recommendations along with soft law agreements. In order to achieve their goals, they interact with a variety of stakeholders to mobilize resources and connections for policy change. They use this kind of city diplomacy to demand increasing competences and resources not only in integration but also in migration policies.

In the concept of transmunicipal solidarity, we capture these joint actions amongst municipalities with a focus on local authorities regarding processes of scaling out und scaling up. The concept might help us to understand how and why municipalities have become key actors in responding to a crisis of solidarity between the EU member states. It could also provide insight into how local governments might use a potential window of opportunity to strengthen and widen their competences. Prospectively, this development might produce spill-overs to other policies and even alter the political system of the EU. With the "Urban Agenda" already giving municipalities another regular voice in EU politics, this projection might not be too daring.
The activities of cities and their networks show that many municipalities pursue an active role in the Common European Asylum System. Further studies will have to make an attempt to find out how effectively municipalities can actually change the European approach to migration and refugee reception. For the time being, the emergence of transmunicipal solidarity is just a glimmer of hope in the deadlocked controversy on refugee reception. It is up to member states-especially those who are willing to take in refugees-to encourage the municipalities' quest for more agency in migration politics and refugee reception.

\section{Acknowledgments}

We gratefully acknowledge the scientific guidance of Petra Bendel in the project "When Mayors Make Migration Policy". Furthermore, we thank Marie de Somer for facilitating contacts to interview partners and hosting us at the European Policy Centre during our field research in Brussels. Also, we highly appreciate the cooperation of all our (anonymous) interview partners and Lefteris Papagiannakis. Last but not least, we thank Brigitte Münzel for English language editing. This contribution developed within the framework of the project "When Mayors Make Migration Policy" funded by Stiftung Mercator.

\section{Conflict of Interests}

The authors declare no conflict of interests.

\section{References}

Acuto, M., Morissette, M., \& Tsouros, A. (2017). City diplomacy: Towards more strategic networking? learning with WHO healthy cities. Global Policy, 8(1), 14-22. https://doi.org/10.1111/1758-5899.12382

Acuto, M., \& Rayner, S. (2016). City networks: Breaking grindlocks of forging (new) lock-ins? International Affairs, 92(5). https://doi.org/10.1111/14682346.12700

Agustín, O. G., \& Jørgensen, M. B. (2019). Solidarity and the 'refugee crisis' in Europe. Cham: Palgrave pivot.

Ajuntament de Barcelona. (2018). Barcelona offers to take in 100 refugees from the boat Aquarius. Ciutat Refugi. Retrieved from http://ciutatrefugi.barcelona/ en/noticia/infobarcelonaenbarcelona-offers-to-takein-100-refugees-from-the-boat-aquarius_675055

Aldecoa, F., \& Keating, M. (1999). Paradiplomacy in Action: The foreign relations of subnational governments. London: F. Cass.

Alger, C. (2011). Searching for democratic potential in emerging global governance. International Journal of Peace Studies, 16(2), 1-24.

Balmer, C. (2019). Naples mayor offers to welcome in stranded NGO migrant boat. Reuters. Retrieved from https://www.reuters.com/article/us-europe- 
migrants-ngo-italy/naples-mayor-offers-to-welcome -in-stranded-ngo-migrant-boat-idUSKCN10X14L

Barber, B. (2014). If mayors ruled the world. New Haven, CT: Yale University Press.

Bauböck, R. (2017). Refugee protection and burden-sharing in the European Union. Journal of Common Market Studies, 56(1), 141-156.

Bendel, P. (2018). Wanderungsbewegungen nach Europa: Fester Bestandteil von Politik-überall? [Migration to Europe: An established policy fieldEverywhere?]. Zeitschrift für Ausländerrecht und Ausländerpolitik, 5, 181-228.

Billmann, L., \& Held, J. (2013). Einführung. Solidarität, kollektives Handeln und Widerstand [Introduction: Solidarity, collective action and resistance]. In L. Billmann \& J. Held (Eds.). Solidarität in der Krise. Gesellschaftliche, soziale und individuelle Voraussetzungen solidarischer Praxis [Solidarity in the crisis, social and individual preconditions for the practice of solidarity] (pp. 13-30). Wiesbaden: Springer VS.

Braun, M. (2019). Der Aufstand der Bürgermeister [The rebellion of the mayors]. Zeit Online. Retrieved from https://www.zeit.de/politik/ausland/2019-01/ italien-matteo-salvini-luigi-magistris-migrationfluechtlinge-konflikt

Caponio, T., \& Borkert, M. (Eds.). (2010). The local dimension of migration policymaking. Amsterdam: Amsterdam University Press.

Chan, D. K. (2016). City diplomacy and "glocal" governance: Revitalizing cosmopolitan democracy. The European Journal of Social Science Research, 29(2), 134-160.

Denzin, N. K. (2014). Triangulation. Hoboken, NJ: John Wiley \& Sons, Inc.

Denzin, N. K., \& Lincoln, Y. S. (Eds.). (2011). The Sage handbook of qualitative research (4th ed.). Los Angeles, CA: SAGE.

Durkheim, E. (1933). The division of labor in society. New York, NY: Alexander Street Press.

EU Partnership on Inclusion of Migrants and Refugees. (2017). Action plan partnership on inclusion of migrants and refugees. Brussels: European Comission. Retrieved from https://ec.europa.eu/futurium/sites/ futurium/files/action_plan_inclusion_of_migrants_ and_refugees.pdf

EU Partnership on Inclusion of Migrants and Refugees. (2018). About. Europa. Retrieved from https://ec. europa.eu/futurium/en/node/1727

Eurocities. (2010). Charter on integrating cities. Brussels: Eurocities. Retrieved from http://nws.eurocities.eu/ MediaShell/media/CharterforWebFINAL.pdf

Eurocities. (2018). Migration \& integration. Eurocities. Retrieved from http://www.Eurocities.eu/Eurocities/ issues/migration-integration-issue

European Commission. (2018). What is the urban agenda for the EU? Retrieved from https://ec.europa.eu/ futurium/en/urban-agenda-eu/what-urban-agendaeu
FAZ. (2018). Deutschland nimmt 50 Bootsflüchtlinge auf [Germany takes in 50 boat people]. FAZ. Retrieved from https://www.faz.net/aktuell/politik/ deutschland-nimmt-50-bootsfluechtlinge-auf15693290.html

Finke, B., \& Knodt, M. (2005). Einleitung: Zivilgesellschaft und zivilgesellschatfliche Akteure in der Europäischen Union [Introduction: Civil society and civil society actors in the European Union] (pp. 11-30). In M. Knodt \& B. Finke (Eds.), Europäische Zivilgesellschaft. Konzepte, Akteure, Strategien [European civil society. Concepts, actors, strategies]. Wiesbaden: Verlag für Sozialwissenschaften.

Gläser, J., \& Laudel, G. (2010). Experteninterviews und qualitative Inhaltsanalyse. Als Instrumente rekonstruierender Untersuchungen [Expert interviews and qualitative content analysis]. Wiesbaden: VS Verlag für Sozialwissenschaften.

Hinger, S., Schäfer, P., \& Pott, A. (2016). The local production of asylum. Journal of Refugee Studies, 29(4), 440-463.

Integrating Cities. (2018). What is integrating cities. Integrating Cities. Retrieved from http://www. integratingcities.eu/integrating-cities/home

Karageorgiou, E. (2016). Solidarity and sharing in the common European asylum system: The case of Syrian refugees. European Politics and Society, 17(2), 196-214. https://doi.org/10.1080/23745118.2016. 1121007

Kern, K., \& Bulkeley, H. (2009). Cities, Europeanization and multi-level governance: Governing climate change through transnational municipal networks. Journal of Common Market Studies, 47(2), 309-332. https://doi.org/10.1111/j.1468-5965.2009.00806.x

Kneuer, M., \& Masala, C. (2014). Solidarität. Politikwissenschaftliche Zugänge zu einem vielschichtigen Begriff [Solidarity. Approaches of political sciences to a multilayered concept]. Baden-Baden: Nomos Verlagsgesellschaft $\mathrm{mbH} \& \mathrm{Co}$.

Knodt, M., Tews, A., \& Piefer, N. (2014). Formen der Solidarität in der Europäischen Union [Forms of solidarity in the European Union]. In M. Kneuer \& C. Masala (Eds.), Solidarität. Politikwissenschaftliche Zugänge zu einem vielschichtigen Begriff [Solidarity. Approaches of political sciences to a multilayered concept]. BadenBaden: Nomos Verlagsgesellschaft mbH \& Co.

Kos, S., Maussen, M., \& Doomernik, J. (2015). Policies of exclusion and practices of inclusion: How municipal governments negotiate asylum policies in the Netherlands. Territory, Politics, Governance, 4(3), 1-21. https://doi.org/10.1080/21622671.2015. 1024719

Lecours, A. (2002). Paradiplomacy: Reflections on the foreign policy and international relations of regions. International Negotiations, 7(1), 91-114.

Marchetti, R. (2016). Global strategic engagement. States and non-state actors in global governance. Lanham, MD: Lexington Books. 
Mayer, M. (2018). Cities as sites of refuge and resistance. European Urban and Regional Studies, 25(3), 232-249. https://doi.org/10.1177/0969776417729 963

Mayring, P. (2000). Qualitative Inhaltsanalyse. Grundlagen und Techniken [Qualitative content analysis] (7th ed.). Weinheim: Deutscher Studien Verlag.

Niederhafner, S. (2007). Städte als politische Akteure im Mehrebenensystem der EU. Eine vergleichende Untersuchung der pan-europäischen Interessenorganisationen Eurocities und RGRE unter besonderer Berücksichtigung der Länder Deutschland, Frankreich und Großbritannien (Doctoral dissertation) [Cities as political actors in the EU multilevel system]. Technische Universität Darmstadt, Darmstadt.

Rosenberger, S., \& Müller, S. (2019). Open and closed doors: Local responses to the refugee policy crisis in Austria. In B. Glorious \& J. Doomernik (Eds.), Geographies of asylum. Berlin: Springer.

Roth, L., \& Russell, B. (2018). Translocal solidarity and the new municipalism. Roar Magazine. Retrieved from https://roarmag.org/magazine/municipalistmovement-internationalism-solidarity

Sangiovanni, A. (2013). Solidarity in the European Union. Oxford Journal of Legal Studies, 33(2), 213-241. https://doi.org/10.1093/ojls/gqs033

Sangiovanni, A. (2015). Solidarity as joint action. Journal of Applied Philosophy, 32(4), 340-359. https:// doi.org/10.1111/japp.12130

Scholz, S. J. (2008). Political solidarity. University Park, PA: Pennsylvania State University Press.

Solidarity Cities. (2019). About. Solidarity Cities. Retrieved from https://solidaritycities.eu/about
Solidarity Cities (2017). Solidarity cities. Cities of Migration. Retrieved from http://citiesofmigration.ca/ ezine_stories/solidarity-cities

Stürner, J., \& Bendel, P. (in press). The two-way "glocalization" of human rights, or how cities become international agents in migration governance. Peace Human Rights Governance, 3(2).

Thielemann, E. (2017). Why refugee burden-sharing initiatives fail: Public goods, free-riding and symbolic solidarity in the EU. Journal of Common Market Studies, 56(1). https://doi.org/10.1111/jcms.12662

Van der Pluijm, R., \& Melissen, J. (2007). City diplomacy. The expanding role of cities in international politics. The Hague: Netherlands Institute of International Relations "Clingendael".

Wallaschek, S. (2018). Solidarity in Europe in times of crisis. Journal of European Integration, 32(4), 1-7. https://doi.org/10.1080/07036337.2019.1546980

Weber, M. (1925). Wirtschaft und Gesellschaft [Economy and society]. Tübingen: Mohr.

Welt. (2018). Bonn, Köln und Düsseldorf wollen weitere Bootsflüchtlinge aufnehmen [Bonn, Cologne and Düsseldorf want to take in more boat people]. Welt. Retrieved from https://www.welt.de/politik/article 180058850/Offener-Brief-an-Merkel-Bonn-Koelnund-Duesseldorf-wollen-weitere-Bootsfluechtlingeaufnehmen.html

Zapata-Barrero, R., Caponio, T., \& Scholten, P. (2017). Theorizing the 'local turn' in a multi-level governance framework of analysis: A case study in immigrant policies. International Review of Administrative Sciences, 83(2), 241-246. https://doi.org/10.1177/ 0020852316688426

\section{About the Authors}
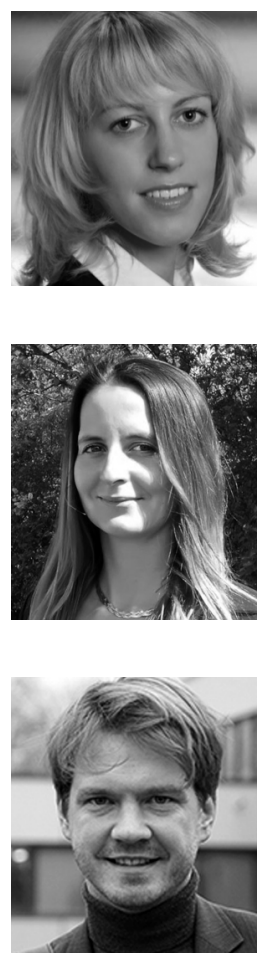

Christiane Heimann is a Postdoctoral Researcher at the University of Hildesheim working on the project "When Mayors make Migration Policy". Previously she conducted research and taught at the University of California Berkeley (USA), University College London (UK), Universidad Pompeu Fabra Barcelona and Universidad Autónoma de Madrid (Spain), Otto-Friedrich-Universität Bamberg as well as Technische Universität Kaiserslautern (Germany). She completed her PhD at the Bamberg Graduate School of Social Sciences (BAGSS) and studied European Social Sciences in Bamberg (Germany) and Salamanca (Spain).

Sandra Müller works as Research Assistant at the University of Hildesheim, Germany. Before she worked in research projects at the Institute of Political Science at the University of Vienna as well as at the Generation and Educational Science Institute, Vienna. Prior to this, she gained practical experience, e.g., as coordinator and project manager in several national and international NGOs. In her PhD project, she explores the politics and policies of asylum in Austria within the analytical framework of Europeanization and De-Europeanization.

Hannes Schammann is Professor of Migration Policy Analysis at the University of Hildesheim, Germany. A good deal of his current research focuses on the role of local administrations in the multi-level governance of migration and asylum. Before turning to academia, he gained extensive experience in the field, e.g., as a policy advisor with the Federal Office for Migration and Refugees in Germany. He is frequently consulted on migration issues by both governments and non-governmental organizations. 


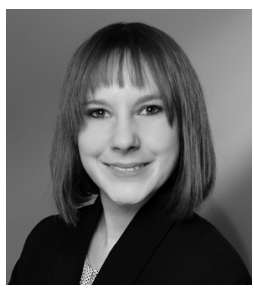

Janina Stürner is a Research Fellow and PhD student at the Centre for Area Studies of the University Erlangen-Nuremberg. Her research analyses migration governance in complex multi-level systems and the changing role of city networks in EU migration, resettlement and asylum policies. In her PhD project, she focuses on migration and development dynamics based on ownership of refugees, migrants and host communities in alternative settings to camps. 